\title{
Enseñar con tecnologías. La maqueta como herramienta con valor didáctico-disciplinar y los modos de aproximación al conocimiento en la enseñanza del proyecto arquitectónico
}

\author{
Marisa Cubalo(1)
}

Palabras clave. proyecto arquitectónico · enseñanza y aprendizaje $\cdot$ tecnologías $\cdot$ nuevos escenarios

Resumen. Este artículo intenta exponer algunas reflexiones sobre los aportes del saber didáctico a las modalidades - tradicionales e innovadorasque conviven en el taller de proyecto arquitectónico, vinculando el rol de los materiales de enseñanza, en términos de tecnología, y la práctica educativa.

En ese sentido, se avanzará, en primer lugar, sobre algunas nociones epistemológicas de la disciplina, la enseñanza del proyecto arquitectónico, como modo de producir y construir conocimiento y las herramientas para la propuesta didáctica. En particular, se procura reconsiderar la función cognoscitiva de la maqueta, haciendo hincapié en la doble experticia didácticodisciplinar y las transformaciones que se han introducido en este escenario educativo con la incorporación de las TIC.
Keywords. architectural design · teaching and learning $\cdot$ technologies $\cdot$ new scenarios

Abstract. This article is aimed at presenting some conclusions about the contributions made by didactic knowledge to traditional and innovative ways that coexist today in the architectural project workshop, linking the role of teaching materials in terms of technology, and the teaching practice.

In that sense, some epistemological notions are developed first on the discipline, teaching the architectural project as a means to produce and build knowledge, and the tools for the teaching proposal. In particular, an attempt is made to reconsider the cognitive function of models, focusing on the dual disciplinary-teaching expertise of those teaching/learning with this device and the transformations introduced to this educational scenario with the incorporation of ICTs.
(1) Facultad de Arquitectura, Diseño y Urbanismo, Universidad Nacional del Litoral. arqcubalo@gmail.com 